\title{
TAGASIVAATEKS HEINO AHVENA 100. SÜNNIAASTAPÄEVAL ${ }^{1}$
}

\author{
TÕNU TENDER, JÜRI VIIKBERG
}

\begin{abstract}
Annotatsioon. Kirjutises vaadeldakse Eesti Teaduste Akadeemia Emakeele Seltsi kauaaegse teadussekretäri Heino Ahvena (1919-1988) elu- ja tööaastaid. Ülevaade sisaldab nii üldteada, vähe tuntud kui ka seni päris varjul olnud seiku. Põgusalt jälgitakse tema haridusteed, mida pikendasid ja varjutasid Teise maailmasõja aastad. Arhiividokumentide abil valgustatakse tema viibimist Saksa sõjaväes ja vangisolekut nii Saksa kui ka Nõukogude ajal. Seejärel vaadeldakse stabiilsemat perioodi tema elus, kui ta jätkas 1945. aastal õpinguid Tartu Riiklikus Ülikoolis ja asus 1947. aastal tööle Akadeemilise Emakeele Seltsi vastutava sekretärina. Pühendunud eesti keelele ja Emakeele Seltsile, asus ta taastama murdekorrespondentide võrku, koostas küsitluskavasid ja seltsi väljaandeid, korraldas ettekandekoosolekuid ja konverentse, kutsus ellu keelepäevad nii maal kui ka linnas. Heino Ahvenat jätkus kõikjale, temast kujunes nii seltsi kui ka keeleürituste hing. Tema mahukat elutööd pole võimalik ei adekvaatselt mõõta ega kaaluda, seda enam väärib see austust ning püsivat meelespidamist.
\end{abstract}

Võtmesõnad: Heino Ahven, Emakeele Selts, eesti keel, keelepäev, murdekogumine

\section{Proloog}

Heino Ahven sündis 11. novembril 1919. aastal Räpinas, kui Eesti riik pidas veel Vabadussõda. Loodearmee rünnakud enamlaste Petrogradi hõivamiseks olid ebaõnnestunud ja valgete väed põgenesid Eestisse. Vabariigi valitsus otsustas „11. nov. 1919 kõigilt neilt Loodearmee osadelt,

1 Kirjutis tugineb Emakeele Seltsi 08.11.2019. a ettekandekoosolekul peetud kahele ettekandele: Tõnu Tenderi „Heino Ahvenast (11.11.1919-22.04.1988) arhiivitoimikute valguses“ (2019a) ja Jüri Viikbergi „Heino Ahven keelepäevade karussellis“ (2019). Esimesest ettekandest on lähtunud ka Tenderi „Kujuteldav kiriusutelu Heino Ahvenaga“"(2019b). 
kes taganevad eestlaste vägede seljataha, relvad ära võtta ja koondada väed Virumaa idaossa" (Traksmaa 1992: 193). Just sel päeval sündiski Ferdinand ja Berta Ahvena perre kolmas poeg Heinrich. ${ }^{2}$ 1934. aastal muutis ta oma nime ise Heinoks (EAA: 41).

\section{Lapsepõlv ja noorukiiga}

Heino Ahvena lapsepõlv ja noorukiiga möödusid Eesti Vabariigis. Ta õppis 1927-1933 Räpina algkoolis, 1934-1937 Võru keskkoolis ning 1937-1941 Tartu Õpetajate Seminaris. Molotovi-Ribbentropi pakti sõlmimise ajal, 1939. aasta augustis oli ta 19-aastane. Ta nägi punasõdurite saabumist Eestisse ja iseseisva Eesti riigi lõppu. Nägi oma silmaga punase kurjuse aastat (1940-1941). Nägi

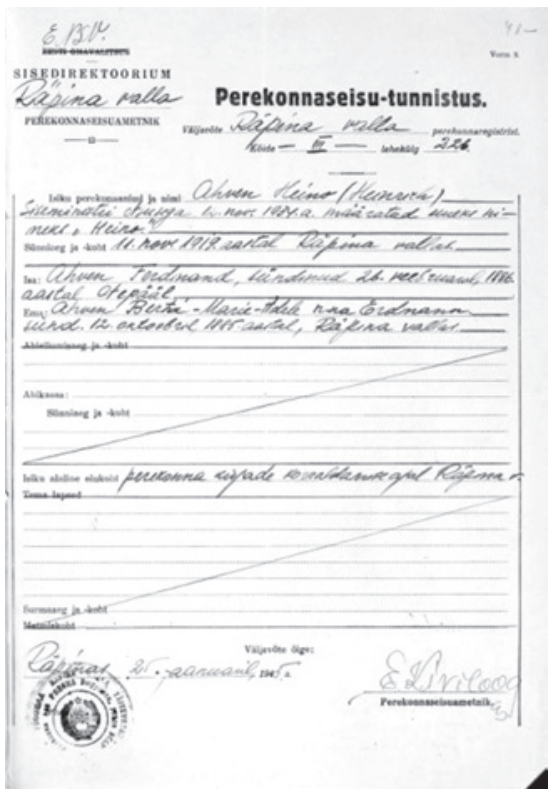

Joonis 1. Vanemate pandud nimest sai eestistamise järel Heino (EAA: 41) 1941. a juuniküüditamist, kirjutas sellest paar luuletustki, nt ,Jõulutervitus kaugelt“" (1942) (Ahven 2002: 97-98). Üks tema õpetajaist, Tartu Õpetajate Seminari direktori kohusetäitja Jüri Parijõgi hukati Tartu vanglas 9. juulil 1941 (keskkooli lõputunnistuse ärakiri, millel on Parijõe nimi, on Ahvenale väljastatud 7. juunil 1941 (EAA: 42)).

Saksa sõjamasin veeres 1941. aasta suvel nõnda kiiresti Eestisse, et teda ega paljusid teisigi ei jõutud taganevasse punaväkke mobiliseerida. 1941-1943 oli Heino Tartu Õpetajate Seminari harjutuskooli (algkooli) õpetaja ning 1942-1943 õppis Tartu ülikoolis eesti filoloogiat.

2 Heino Ahvenal oli kolm venda: Agu (1912-1987), Lembit (1916-2006) ja Kalju (1921-1946). Kirjanduslike huvidega, sh „kirjasulepalavikuga“ olid Lembit, Heino ja Kalju. Neist kõige osavama sulega oli varalahkunud Kalju. Otto Webermann kogus tema käsikirjad kokku, kirjutas neist doktoriväitekirja (1951) ning üllitas luulekogu „Kas mäletad?“ (1956) (vt Ahven 2002: 3-5). 


\section{Saksa okupatsiooni ajal Tartu vanglas}

Heino Ahvena luuletuses „Eestlaseks ma olen sündind“ (1944/45) sisaldub mõte, kuidas kaks suurt naabrit Eesti eest „,hoolt kannavad“ (Ahven 2002: 101). Ahven sai tunda nii Saksa kui ka Vene okupatsioonivõimu kinnipidamisasutusi, st ta oli vangis mõlema režiimi ajal. Esimene vangistus oli suhteliselt lühiajaline, kuid määras paljuski ära tema edaspidise saatuse. Saksa okupatsiooni aegse vangisoleku kohta on säilinud mitu dokumenti, Vene-aegse kohta mitte.

Aatelise inimesena soovis Heino Ahven Eesti iseseisvuse eest võidelda. Tõenäoliselt pidas ta koos noorema venna Kalju ning veel mõne teisega 1943. aastal plaani Soome põgeneda, et hõimuvendade armees vaenlaste vastu võidelda. Paraku läks plaan luhta, sest nagu osutavad ajalooallikad, vahistas noormehed Eesti julgeolekupolitsei.

Määrus. Tartu Peavälisosakonna poliitilise politsei peareferent võtnud arvesse, et kod. Ahven, Heino Ferdinandi p. sünd. 11.11.1919. a elukoht Tartus, Taara puiestee 7-1 peale langeb põhjendatud kahtlus maksva korra vastu sihitud tegevuses, seepärast $\mathrm{m}$ ä är a s: kod. Ahven, Heino pidada kinni julgeoleku huvides. „13“ märtsil 1943.a. kell 17.30 Peareferent (allkiri). (ERA: 2)

Poliitilise politsei peareferent on saatnud vahistatu Tartu vangimajja koos saatekirjaga direktorile.

Saadan siinjuures pöördelmärgitud vahialuse [Ahven, Heino] kinnipidamiseks vangimajas poliitilise politsei järgi. Tartus, „13“ märtsil 1943. a. (ERA: 2p)

Ahvena vanglatoimiku vahel sisalduvas ankeedis (teateleht) on kirjas tema isikuandmed ja välised tunnused.

/.../

7. Haridus Seminar

8. Perekondlik seis Vallaline

9. Millist abi andis perekonnale [lahter on täitmata]

10. Varanduslik seis Varanduseta

11. Kutse (amet) Kooli õpetaja

12. Lähemad omaksed (nende nimi, asukoht, tegevus, käitumine) Isa Ferdinant ema Berta elavad Räpinas 
Vend Agu elab Rannus

Vend Lembit elab Tallinnas Koidu tn 120-11

Vend Kalju vahi all Tartu vanglas.

13. V/a usk Lutteri

14. Abielu- või vallaslaps

15. Käitumine perekonnas, ühiskonnas, võimudega [lahter on täitmata]

16. Eelkaristused /.../ Karistamata

/.../

Punkt 22: vahistatu tunnusmärgid:
a) kasv $177 \mathrm{~cm}$
k) näpujälg [näpujälge pole võetud]
b) nägu sale
c) silmad sinised. juuksed blondid.
d) vurrud
f) nina sirge.
g) füüsilised defektid ei ole. (ERA: 1, 1p)

Vangiaktil on märge, et Heino Ahven paigutati Tartu vangimajja 13. märtsil 1943 ja vabastati sealt 18. märtsil 1943.

Määrus. 18. märtsil 1943. a. Tartu Peavälisosakonna Poliitilise Politsei Peareferent võtnud arvesse, et kodanike Heino A h v e n, sünd. 11.11.1919.a., Kalju A h v e n, sünd. 11.09.1921.a., Kaljo S o o s a a r, sünd. 02.09.1917.a., Helmut T a i m r e, sünd. 05.12.1917.a. ja Aleksander L u i k'i, sünd. 31.01.1916.a. kinnipidamine juurdluse huvides ei ole enam vajalik, seepärast $\mathrm{m}$ ä ä $\mathrm{r}$ a $\mathrm{n}$ : kodanikud Heino A h v e n, sünd.11.11.1919.a., Kalju A h v e n, sünd. 11.09.1921.a., Kaljo S o o s a a r, sünd. 02.09.1917.a., Helmut T a i m r e, sünd. 05.12.1917.a. ja Aleksander L u i k, sünd. 31.01.1916.a. vahialt vabastada. „13“ märtsil 1943. a. kell 17.30. $\quad$ B. Juht. Peareferent (ERA: 3)

Eespool kirjeldatule heidab valgust nõukogude julgeolekuorganitele (KGB) 28. juulil 1962 esitatud arhiividevalitsuse dokument nr 02195. Ainueksemplaril on märge ,salajane“.

ENSV RJK 2.osakonna ülemale polkovnik sm. Kiseljov'ile. T/nr.3/S179 - 13. juulist 1962.a.

ENSV Oktoobrirevolutsiooni Riiklikus Keskarhiivis arvelevõetud dokumentaalsete materjalide ja säilitatud erikartoteegi andmeil:

A h v e n, Heino Ferdinandi p., sünd. 11.nov.1919.a. Räpina vallas (teistel andmetel Räpina alevikus), elanud Tartus, Taara puiestee 7-1, rahvuselt eestlane, Eesti kodakondsusega, gümnaasiumi haridusega (teistel 
andmetel seminari haridusega), elukutselt kooliõpetaja, oli vallaline on arvele võetud saksa okupatsiooni aegses Eesti Julgeolekupolitseis kui isik, kes tahtnud salaja Soome minna. Vahistatud 13.märtsil 1943.a.

17. märtsi 1943.a. otsus: tehtud riigipolitseiline hoiatus ja võetud kohustus-allkiri, et ta loobuks elukoha muutmisest ilma politseile teatamata ja ka kavatsusest Soome pääsemiseks. Asunud teenistusse 35.politsei pataljoni, Tallinna, Tartu mnt.64.

Ka esineb ta saksa okupatsiooni aegses Tartu Vangla fondis säilitatud tema nimele koostatud vangiaktis - 1943.a. kui isik, keda vahistatud ja paigutatud kinnipidamiseks Tartu vangimajasse 13.märtsil 1943.a. Vahi alt vabastatud 18.märtsil 1943.a. Tähendatud on, et ta olnud kinnipeetav poliitilise politsei järele.

Alus: Saksa okupatsiooni aegne Eesti Julgeolekupolitsei kartoteek.

Fond R-292, nim.1, arh.45, lht.3; arh.44.

A h v e n, Heino, sünd.1919.a., elanud Kroonuaia 24-1, õpetajate seminari haridusega (muid andmeid ei tähendata) - on arvele võetud saksa okupatsiooni aegses Eesti Julgeolekupolitseis 6.nov.1942.a. kui isik, kes kogutud andmeil osutunud poliitiliselt ustavaks.

Alus: Saksa okupatsiooni aegne Eesti Julgeolekupolitsei kartoteek.

Kuid andmeid ei ole leitud.

Lisa: Järelpärimine nr. 021951 lehel ainult adressaadile.

ENSV Oktoobrirevolutsiooni Riikliku Keskarhiivi ülem: K. Ingermann Erifondide osakonna ülem: H. Kaldas (ERAF: 9)

\section{Sundmobiliseerituna Saksa sõjaväes}

18. märtsil vanglast vabanenuna mobiliseeriti Heino Ahven kohe Saksa sõjaväkke, 35. politseipataljoni, kus tegutses kirjutajana Tallinnas, Tartus ja Rakveres. Lahingutegevusest ta osa ei võtnud (elulookirjeldus, ERAF: 43-44).

35. politseipataljon taandus 1944. aastal venelaste lähenedes koos sakslastega varakult Saksamaale ning kuuldavasti liideti seal 20. Eesti SS-diviisiga. ${ }^{3}$ Septembris 1944 enne laevale asumist põgenes aga Ahven koos ühe kamraadiga Häädemeeste kandis sõjaväest, st deserteerus. Üks Saksa ohvitser märganud poiste minekut, kuid häiret ei andnud. ${ }^{4}$

\footnotetext{
3 http://www.eestileegion.com/?eesti-leegion/ueksused/politseipataljonid.html (04.03.2020).

4 Heino Ahvena väimehe Einart Kimmi suulised andmed sügisel 2019.
} 
Pärast Saksa sõjaväest deserteerumist siirdus Heino Ahven Tallinna, kus sai vend Lembitu abiga oktoobris 1944 tööd Tallinna Telefonivõrgus (korrastajana, hiljem joonestajana). Ta püüdis jätkata õpinguid Tartu ülikooli kaugõppes ning saatis ülikooli kantseleile 20. oktoobril 1944 kirja: tema soov oli saada tõend, et ta on olnud Tartu ülikooli filosoofiateaduskonna üliõpilane (EAA: 1).

\section{Vangilaagris}

Ülikooli tõendit Heino Ahven ära oodata ei jõudnud. 25. oktoobril 1944 paigutati ta kui Saksa sõjaväes teeninu Maardusse sõjavangide laagrisse. Seda nimetati nii NKVD erilaagriks kui ka kontroll- ja filtratsioonilaagriks ${ }^{5} \mathrm{nr} 0316$. Vangilaagrist vabanes ta 12. juunil 1945 (ERAF: 66;

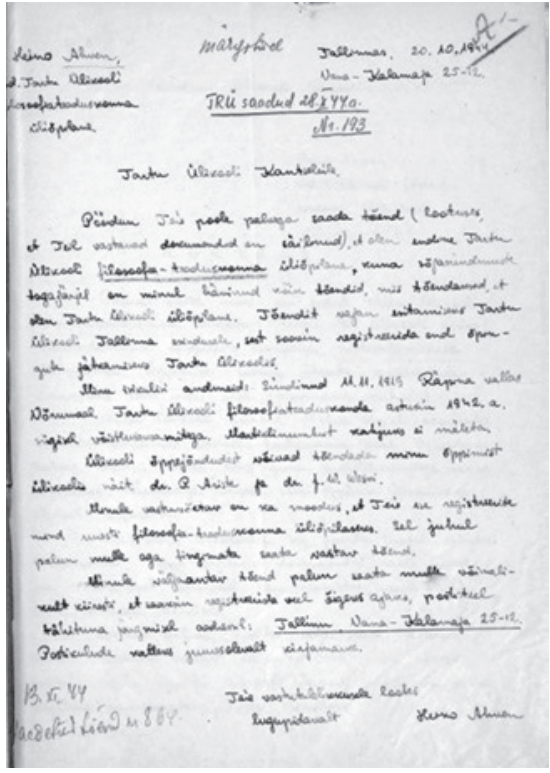

Joonis 2. Heino Ahvena kiri Tartu ülikooli kantseleile 20. oktoobril 1944 (EAA: 1) EAA: 3). Okastraaditagust aega peegeldab tema luuletus „Mälestus Maardust“ (1945/47) (Ahven 2002: 102).

Heino Ahvena noorem vend Kaljugi mobiliseeriti Saksa sõjaväkke, kuid ta sattus vangilaagrisse ja suri 1946. aastal Lübeckis (Saksamaal) tuberkuloosi. Kalju surm mõjus lähedastele rängalt, kaks vanemat venda kirjutasid tema mälestuseks mitu luuletust.

\section{Ülikooliõpingud}

Pärast vabanemist asus Heino Ahven taas tööle Tallinna Telefonivõrgus. Augustis 1945 kirjutas ta avalduse, kus soovis, et ta kui endine üliõpilane

\footnotetext{
5 Kontrolli- ja filtratsioonilaagrid ,ei erinenud millegi poolest parandusliku töö laagritest, vahe oli ainult selles, et neisse paigutatud isikutele polnud karistus veel määratud, nad pidid selle saama alles laagris ... Vabal ajal - õhtuti ja öösiti - kuulati kontrollitavaid üle ... Nagu alati, alustati uurimist teesist, et sa oled ilmtingimata süüdi. Sina pidid nüüd okastraadi tagant välja pääsemata tõendama, et sa ei ole süüdi.“ (Solženitsõn 1990, kd 1: 198).
} 


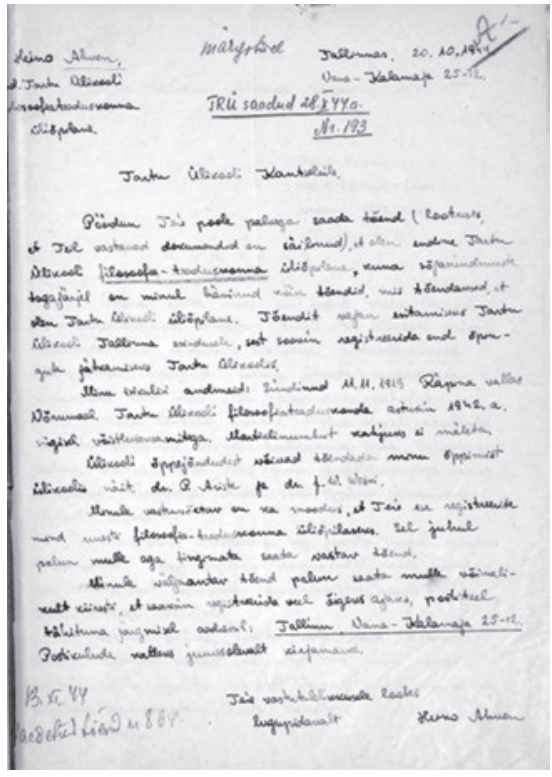

Joonis 3. Heino Ahvena

selgitused ülikoolile akadeemiliste võlgnevuste kohta (EAA: 13 jj) lisataks mittestatsionaarse üliõpilasena Tartu ülikooli ajaloo-keeleteaduskonna üliõpilaste nimekirja. Ta soovis õppimist jätkata keeleteaduse osakonnas eesti keele alal kirjanduse eriharus. (EAA: 2)

Ülikooliõpingute aeg kujunes pikaks: Heino Ahven lõpetas ülikooli 1956. aastal eesti keele erialal. Tal tekkisid ülikoolis aeg-ajalt akadeemilised võlad, eriti võõrkeeltega: ladina, inglise, vene ja soome keelega. Algul tekitas tõrkeid õppekavade hiline kättesaamine, seejärel tema vilets tervislik seisund (nõrgad kopsud). (EAA: 13 jj) Peamine oli siiski see, et täistöö kõrvalt ülikoolis õppimine ei olnud kerge. 15. jaanuaril 1947 oli ta tööle asunud Tallinna 21. Keskkoolis õpetajana. 1. juulist 1947. asus tööle Akadeemilises Emakeele Seltsis. 1953. aastal abiellus Heino Ahven Eeva Kurvega (Ahven).

\section{Heino Ahven ja Emakeele Selts}

Ajalooallikate andmeil taastati pärast Teise maailmasõja lõppu Akadeemilise Emakeele Seltsi (AES) tegevus Tartu ülikooli juures 22. septembril 1945. Eesti NSV Teaduste Akadeemia loomise järel viidi aga selts 31. mail 1946 üle teaduste akadeemia alluvusse. Järgmisel, 1947. aastal loodi vastutava sekretäri ametikoht ja seltsi tegevus hakkas tasahilju ilmet võtma. Kui lõppes ajutise kohusetäitja Asta Hameri ametiaeg (12.05-30.06.1947), alustas 1. juulil 1947 vastutava sekretärina tööd Heino Ahven. Ta oli mittestatsionaarne üliõpilane (nagu oli ka Hameri) ega osanud veel aimata, et seltsist saab tema töökoht enam kui 40 aastaks. 


\section{Murdekeele kogumine}

Sõja-aastad ja võõrvõimud olid kõvasti räsinud nii ühiskonda kui ka seltsi. Vastutava sekretäri põhitööks pidi saama varasema murdekorrespondentide võrgu taastamine, et jätkata vanapärase keeleainese talletamist (Ahven 1955: 17). Uutes oludes olid inimesed pelglikud ja umbusklikud, seetõttu tuli alustada inimsuhetest ning taastada usalduslik omainimeste keelekogukond.

Korrespondentide võrgu looja ning juhendaja Hella Keem oli oma „nõukogudevastase“" tegevuse eest vangistatud, kuid kasutada sai tema kaastööliste nimestikke ja elukohaandmeid. Toeks olid allesjäänud ülikooliõppejõud ning seltsi juhatuse liikmed, nagu ka vast loodud Keele ja Kirjanduse Instituudi keeleuurimissektori töötajad. Tuli võtta ühendust seniste murdekogujatega ja taasalustada nendega vahetut suhtlust - olid nad ju seltsile kohalikud tugiisikud. Selleks tegi Heino Ahven murdekogumisega lähemat tutvust ka ise. Tema koduarhiivis säilinud materjalid osutavad, et esimesed murdematkad viisid teda Pöide kihelkonda Saaremaal (augustis 1948) ja Simuna kihelkonda Rakkesse (juulis 1949).

Saaremaast oli saanud nõukogulik piiritsoon ja sinna sõitmiseks läks vaja eriluba nii tsiviil- kui ka sõjaväevõimudelt. Miilitsaosakonna ülem Vakk andis kodanik Heino Ahvenale loa ,läbi viia temale antud ülesannet Akadeemilise Emakeele Seltsi ülesannete täitmisel“ ja nõustus

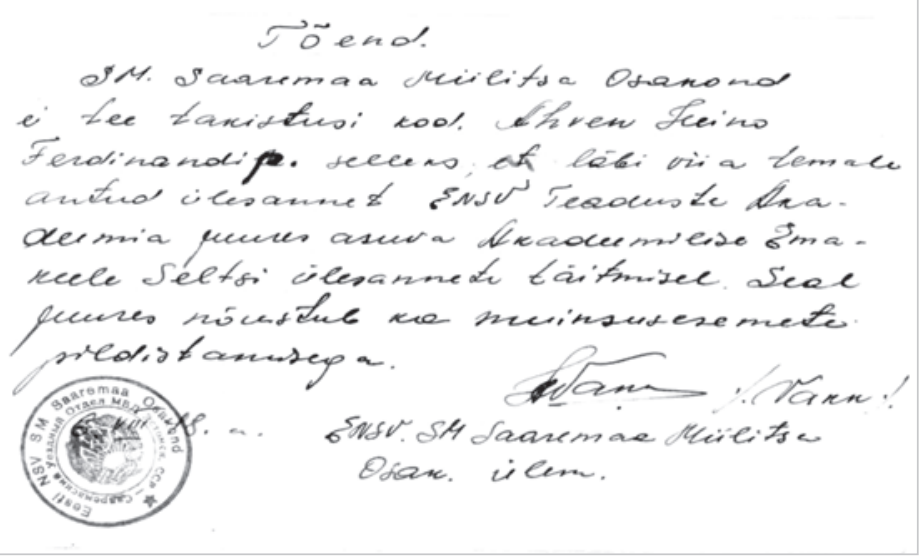

Joonis 4. Dokument, mis tagas 1948. aastal pääsu piiritsooni (allikas: perekonnaarhiiv) 
muinsusesemete pildistamisega. Nõukogude piirivalve staabiülem alampolkovnik Tšernõšov andis loa liikuda ja pildistada Laimjala, Leisi, Torgu ja Kihelkonna vallas, ühtlasi kohustades teda oma tegevusest, ,pildistamisperioodil" informeerima piirivalvekomandantuuri.

1948. aasta pagineerimata matkapäevikust ilmneb, et Saaremaal huvitus Ahven peamiselt tuulikutest. Neid otsides sõitis ta esiti Kuressaarest Torgu valda (Jäm), seejärel Lümandasse (Khk), Valjalasse (V1l) ja lõpuks Laimjalga (Pöi). Lülle, Kuusnõmme, Rahuste ja Viltina külast on ta kirja pannud veskitega seotud terminoloogiat ja lühemaid tekstinäiteid foneetilises transkriptsioonis ning lisanud sinna veskiosade jooniseid. Kui teistes valdades liikus ta omapäi, siis Laimjalas saatis teda AESi kaastööline Aadu Toomessalu ja viis ta kokku oma keelejuhtidega. Viltina külas on Ahven joonistanud paberile sealse pukktuuliku, Villemi tuulingu läbilõike ning kirjutanud Andrei Kruusi (72) suust üles pukktuuliku „sünniloo“6.

Pukktuulingu sünnikoht on Saksamaal Reini jöe ääres. Karjapoiss on tiiva leidand anesulest, teda on akadud täiendama ja täiendama, kuni selle aeani, mis meil on, see on kolmsada kolmkümmend aastat tagasi mu rehnungi järele. Sääl on ta sündind ja muud ma ei tea selle kohta midagi rääkida.

Ahvena märkmed on kaunis napid ja päevik jäänud lõpetamata. Kui aga heita pilk kas või Toomessalu ülevaatele Laimjala tuulikutest (Toomessalu 1955), siis on ilmne, et mõlemad mehed on liikunud tollal samadel kogumisradadel.

Tööstustemaatikaga tutvumiseks sõitis Ahven 1949. aastal Rakkesse, kus tegutses tuntud lubjatehas. Sihtkoha valik oli seotud Helmut Joonuksiga, kohaliku koolmeistri ja seltsi endise kaastöölisega (mh tema sõjaväekaaslasega). Säilinud on Ahvena märkmeid töö kohta paemurrus ja lubjapõletamisest, ent needki ülestähendused on jäänud puhtaks kirjutamata ja päevikusissekanded pooleli. Seevastu kodukandis Räpinas õnnestus tal keeleainese kogumine palju paremini. 1947. aasta suvel talletas Ahven Räpina paberivabriku ja paberitootmisega seotud sõnavara ning tekste, millest väljavalitud paremik on näinud hiljem trükivalgust (Ahven 1970).

Neil murdematkadel sai Ahven omal nahal tunda, mida keelematerjali kogumine endast kujutab. Murdeinimeste ja -keelega jäi ta aga tihedalt seotuks edaspidigi. 1958. ja 1961. aasta suvel on ta koos Mari Mustaga

${ }^{6}$ Siinkohal esitatud lihtsustatud transkriptsioonis. 
lindistanud Aadu Toomessalu jutustamist, 1960. aastal on ta Mari Musta, Aino Kaljuste ja Helju Kaaluga tutvunud Läänemaa murdekõnelejatega, lindistades keelenäiteid üheksast kihelkonnast.

Murdekogujate võrgu taaselustamiseks tuli inimeste poole pöörduda nimeliselt kirja teel ja 1947. aasta lõpuks oli saadud tagasisidet 35 korrespondendilt. Nii nagu varasematel aegadel, ootasid murdekogujad seltsilt küsitluskavu, nõu ja juhtnööre. 1947. aasta sügisel valmiski viis uut küsitluskava, ent nende paljundamisest kirjutusmasinal ei piisanud ja trükki jõudsid need alles 1949. aastal. (Ahven 1955: 17)

\section{Näguripäeva-aastad}

Sõja lõpp ei tähendanud paraku eestlastele kannatusaastate lõppu. Sundkolhoseerimine, plaanimajanduslik küüditamine ja nn kodanlike natsionalistide paljastamine lõid reaalse hirmuühiskonna, mille abil Moskva võim end Eestis kehtestas, põlustades kõike, mis oli seotud meie varasema iseseisvuse ning rahvuskultuuriga. 1950. aastal pidi oma tegevuse 1õpetama Õpetatud Eesti Selts ja sama saatus ähvardas ka Akadeemilist Emakeele Seltsi, sest teaduste akadeemia presiidiumi arvates (16.02.1950) ei olnud seltsi töö küllalt tulemusrikas. Seepeale korraldas selts 21. mail Tartus konverentsi Nikolai Marri keeleõpetuse kohta ja pälvis akadeemia juhtkonna heakskiidu. Kui 1951. aasta algul tutvustati teaduste akadeemia presidendile Johan Eichfeldile murdekorrespondentide kaastöid, oli ta neist põllumajandusteadlasena vaimustunud. Ometi pidas akadeemia presiidium seltsi likvideerimist jätkuvalt vajalikuks ja saatis 14. mail seltsile sellekohase teatise. Seepeale läks vastutav sekretär Heino Ahven Toompeale, et seletada akadeemikutele rahvakeele kogumise ja uurimise vajalikkust ning tähtsust. Sellele järgnes 14. detsembril seltsi kollektiivne pöördumine (Ahvena sõnastuses), milles rõhutati eriti Stalini keeleteaduslike tööde virgutavat mõju AESi tegevusele. See mõjus, selts jäeti likvideerimata. (Neetar 2005: 230)

\section{Seltsi väljaanded}

Vastutava sekretäri järgmiseks pidevaks töökohuseks kujunes seltsi väljaannete koostamine ning trükkitoimetamine. Murdekorrespondentide tarvis ilmus aastail 1949-1958 seitse vihikut „Kogumistöö juhendaja eesti keele 
alal“. Neis avaldati küsitluskavu (nt „Sepp“, „Saun“, „Rätsep“, „Leib“), näiteid kogutud murdetekstidest ja ülevaateid tehtud tööst, neil veergudel jagati kogemusi. 1950. aastate keskpaiku muutus elu pisut hapnikurikkamaks ja sõna võis hakata rohkem levima. Teaduslike väljaannetena alustasid ilmumist seltsi aastaraamat (ESA, 1955) ja toimetised (EST, 1958). 1960. aastal lisandus neile Kodumurre, mis vahendas korrespondentide ja keeleteadlaste koostööd, ent avaldas ka laiemale üldsusele huvipakkuvaid keelekirjutisi. Seltsi publikatsioonidega Ahvena töökoormus muidugi kasvas, aga ta oligi rahutu hing, kes endale ise üha tegevust otsis. Ta asus koostama korrespondentide tekstikogusid ja esimesed valimikud murdetekste ilmusid 1956., 1957. ja 1969. aastal. Kõik plaanitu siiski ladusalt ei teostunud. Kas või sellepärast, et trükivõimalused jäid ikka rohkem ajale jalgu ja see võis võtta tööisu, ent ega kõigele plaanitule jätkunud ka aegavõhma. Et Ahvena käe alt käisid läbi kõik seltsi väljaannete käsikirjad, siis tuli neist nii mõnigi oma aega kauemaks ootama panna. Mõne käsikirja toimetamine aga jäigi pooleli ja jõudis kaante vahele hoopis hiljem teiste kaasabil, näiteks Gustav Vilbaste „Eesti taimenimetused“ (1993) või Theodor Saare „Kihnu raamat““ (1998).

\section{Keelepäevad}

Emakeele Seltsi tegevuse põhivormiks on olnud ettekandekoosolekud Tallinnas ja Tartus. Et keeleteadlaste sõna laiemalt kuuldavaks teha, hakati korraldama loengupäevi üle kogu Eesti. Uus tava sai alguse 1961. aastal Viljandi keelepäevast, kus Tartu Riikliku Ülikooli õppejõud ja Keele ja Kirjanduse Instituudi teadlased kõnelesid keeleküsimustest ning oma tööst (Tender 2000: 126-129). Esimene üritus äratas tähelepanu ja huvi ning seltsi saabusid varsti soovid korraldada keelepäev Elvas, Võrus ja Märjamaal, hiljem juba muljalgi.

Keelepäevade hingeks kujunes algusest peale Heino Ahven, kes andis korraldajatele soovitusi temaatika ja esinejate kohta, pidas läbirääkimisi esinejatega, hoolitses kutsete trükkimise eest jms. Oluline oli saada keelepäevale kõnelema sõnaosavaid keeleinimesi, kuid sama tähtsaks pidas Ahven, et sõna saaksid ka kohalikud õpetajad ning vanemate klasside õpilased. Juba mõne aastaga ilmnes, et kohapealne nõudlus keelepäevade järele on suur (Neetar 2005: 233-234). Poliitilise vabaduseta rahva tähelepanu keskendus emakeelele ja keelepäevadest sai alguse rahvaliikumine 
Lugupeetud

Palume Teid osa võtta

EMAKEELE SELTSI SAJANDAST,

MARJAMAA KESKKOOLI

KUMNENDAST KEELEPAEVAST

A. Lauteri nim. Märjamaa Keskkoolis

(Tamme tee 1) neljapäeval, 1. novembril 1984. Algus kell 11.

Eesti NSV Teaduste Akadeemia

EMAKEELE SELTS

A. Lauteri nimeline

MXRJAMAA KESKKOOL

Papla Rajooni RSN TK Haridusosakonna METOODIKAKABINET

\section{PÄEVAKORD:}

\section{(f. 1)}

Emakeele omandamise ideoloogilistest aspektidest.

Avasōna

- JUHAN KAHK, ENSV Teaduste Akadeemia Uhiskonnateaduste akadeemiksekretär

Emakee'e Seltsi 100 keelepäeva

- HEINO AHVEN, Emakeele Seltsi teadussekretär

Märjamaa keelepäevad

- ANNELY VILLMANN, Mărjamaa Keskkool 10 Xla kl. opilane

Eesti Rahvuskorpuse sĩdurite erikeelest

- JUHAN PEEGEL, Tar.u Riikliku Olikooli iG professor, zur:alistika kateedri juhataja

Kui kaua me oleme olnud reestlaseda

- HUNO RXTSEP, Tartu Rikliku Ulikool professor, eesti keele katcedri juhataja, Emakeele Seltsi esimees

Mälesłusi murdematerjali kogumiselt

Märjemaal (1926)

- ARNOLD KASK, Tartu Rikliku Olikoolt professor

Mida me peaksime teadma murdest in EEVI ROSS. ajakirja eKeel ja Kirjandus" 100
vastutav sekretä:

Vananenud ja murdesõnad Ma's Trądi remanis "Puud olid, ptud olid helled velled $x$

- VILMA LEHTSAAR, Märjamaa Keskkooli Xla kl. ôpilane

Joonis 5. Emakeele Seltsi 100. keelepäev Märjamaa keskkoolis 1. novembril 1984 (allikas: perekonnaarhiiv)

eesti keele kaitseks, mistõttu ei pandudki imeks, et just Emakeele Selts andis hoogu emakeele hingestatud toetusele rahva seas. Kindlasti oli see üks põhjusi, miks Heino Ahven tundis end keelepäevadel päris omas elemendis.

Aastaks 1984 oli jõutud juba 100. keelepäevani, mis toimus Märjamaal, ent keeletuhin jätkus tõusvas joones. 1988. aasta jooksul peeti koguni 18 keelepäeva, nt 05.04 Järva-Jaani kutsekeskkoolis, 06.04 Maarja keskkoolis, 07.04 Tõrva keskkoolis, 14.04 Kingissepa 3. keskkoolis, 21.04 Värska keskkoolis ... Ja siis aeg peatus. Värska keelepäev oli viimane, kus Heino Ahven esines, ning 19. mail 1988 toimunud Vana-Vigala keelepäev oli viimane, mille ettevalmistamisel ta osales. Nii sai Heino Ahvena keelepäevi kokku 144. Tagantjärele tundub, et nii nagu vajasid keelepäevade loenguid ja sõnavõtte rahvustunde tõusulaines kuulajad, nii toitsid need päevad ka korraldaja Heino Ahvena enda hinge. 


\section{Teeneline kultuuritegelane}

Heino Ahven ei osanud end puhtalt keelemeeste kilda arvata, sest tema huvid ja tegemised käisid palju laiemas kaares. Aktiivselt lõi ta kaasa Tallinna Teadlaste Maja tegemistes kohe selle algusest alates (1966), ta laulis teaduste akadeemia meeskooris dirigent Arvo Ratassepa käe all, ta juhtis kirjandusõhtuid Tuglase majamuuseumis, ta oli suur luuletundja ja ka ise sädemega luuletaja, ta oli isegi kirglik maletaja. Heino Ahven oli nii kultuuritarbija kui ka -looja, tema loomuliku keskkonna moodustaski kultuur iga võimalikul moel, ja pole midagi imestada, et 1985. aastal omistati talle Eesti NSV teenelise kultuuritegelase aunimetus. ${ }^{7}$

\section{Enesekaemus ja kõrvaltvaade}

1964. aastal kirjutas 45-aastane Heino Ahven mõistuloo „Üks teaduslik tõsilugu“, mis kirjeldab arutelu mahuka käsikirja toimetamise ümber ühe teadusliku ühingu koosolekul (vt Ahven 2005). Kujuteldaval koosolekul on kohal tähtsad akadeemikud ja professorid ja doktorid ning üks parimais aastais mees, ühingu teaduslik sekretär, ilma ühegi tiitli või kraadita. Laual on käsikiri, 1200 lk paks, mida tuleks toimetada. Kellele see ülesandeks anda? Kellele muule kui teaduslikule sekretärile, professorid ja doktorid on ju üliväga hõivatud. Las otsib mees 10-20 spetsialisti, näitab neile töö kätte, juhendab ja pärast ühtlustab. Lihtne lugu. Kui sekretäri arvates oleks tal vaja pigem oma väitekirja kirjutada, on ka sellega kõik päri. Sekretäril on selleks ju korraline puhkus. Pealegi, ega see käsikiri ju rohkem aega võta kui kolm kuud. Lihtne lugu. Ja asi kujuneski nii, et sekretär kratsis küll kukalt, kuid hakkas usinalt 1200-leheküljelist käsikirja lappama.

Mõistulood pole harilikult tõest kuigi kaugel. Selleks käsikirjaks oli tõenäoliselt Gustav Vilbaste „Eesti taimenimetused“, mida Heino Ahven hakkas 1959. aastal toimetama koos Erast Parmastoga. Teos ilmus lõpuks 1993. aastal Emakeele Seltsi toimetiste 67. köitena, kui Heino Ahvena asemele olid asunud Eeva Ahven ja Eevi Ross. Teoses on 706 lk. Eessõnas ütleb Erast Parmasto (1993: 14) muu hulgas järgmist.

7 Veidi ebaharilik oli vast see, et esildise tegi Keele ja Kirjanduse Instituudi direktor Endel Sõgel (26.06.1985), kes palus Ahvenale toetust parteisekretär Karl Vainolt. Sõgel rõhutas, et Lääne nõukogudevastased artiklid ja raadiosaated väidavad, et Eesti NSVs ei hinnata ei eesti keelt ega eesti keeleteadust. Seega oleks Emakeele Seltsi teadussekretäri autasustamine tähtis nii kultuuriliselt kui ka poliitiliselt. 
Ühegi teise teose trükiks ettevalmistamisele ei andnud Heino Ahven nii palju oma ajast ja tähelepanust kui Gustav Vilbaste käsikirjale. Meie sellega seotud töökohtumistel tekitas aukartust ja imestustki tema eriliselt terane toimetajapilk ja selline täiuslikkuse taotlus, milletaolist ma pole teistel kohanud. Toimetamine on raske ja tänamatu töö, mida selleks kutsutud teevad isikliku loomingutöö arvel.

„Eesti taimenimetused“ on väärikas monument Gustav Vilbastele, on aga ka väärikas monument Heino Ahvenale, tema enam kui 12000 lk eesti keele trükiks ette valmistanud toimetajatööle.

\section{Epiloog}

22. mail 1947 kirjutas Arnold Kask Heino Ahvenale ja teatas, et Akadeemilise Emakeele Seltsi juhatuse koosolekul (12.05) peeti tema kandidatuuri kõigile vastuvõetavaks. Kirja lõpetab ta sõnadega: „Töö keele alal on küllaltki huvitav ja ma usun, et Teie oma sammu ei kahetse." Võib olla päris kindel, et Heino Ahven oma sammu ei kahetsenud.

Töötada enam kui 40 aastat ühes ja samas ametis tähendab, et too oli meelepärane. Ta sai olla taastaja, ülesehitaja, hoidja ja innustaja. See töö pakkus võimalust end proovile panna ning pinget kuni lõpuni. Heino Ahven lahkus teispoolsusesse töökohuseid täites reedel, 22. aprill 1988.

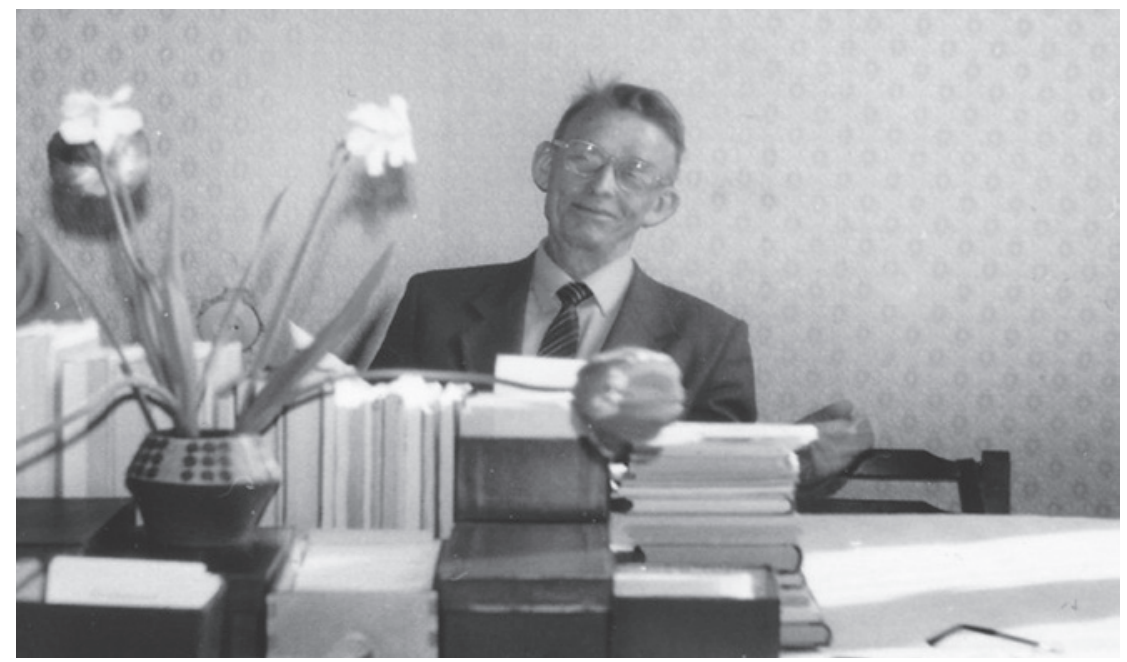

Joonis 6. Keele ja Kirjanduse Instituudi murdesektoris 20. märtsil 1984 (foto: Jüri Viikberg) 


\section{Kirjandus}

Ahven, Eeva (koost.) 2002. Kolm Ahvenat. Kalju, Heino, Lembitu luulet. Tallinn. Ahven, Heino 1955. Emakeele Seltsi tegevusest sõjajärgseil aastail (19451954). - Emakeele Seltsi aastaraamat I. Eesti NSV Teaduste Akadeemia Emakeele Selts. Tallinn: Eesti Riiklik Kirjastus, 5-26.

Ahven, Heino 1970. Vanade paberitööliste juures. Murdepudemeid Räpinast. Emakeele Seltsi aastaraamat 16 (1970). Eesti NSV Teaduste Akadeemia Emakeele Selts. Tallinn: Kirjastus „Eesti Raamat“, 259-272.

Ahven, Heino 2005. Üks teaduslik tõsilugu. - Emakeele Seltsi aastaraamat 50 (2005). Peatoim. Mati Erelt. Tallinn: Eesti Teaduste Akadeemia Emakeele Selts, 241-246.

Neetar, Helmi 2005. Heino Ahvenale mõeldes. - Emakeele Seltsi aastaraamat 50 (2005). Peatoim. Mati Erelt. Tallinn: Eesti Teaduste Akadeemia Emakeele Selts, 228-240.

Parmasto, Erast 1993. Kaastoimetajalt. - Gustav Vilbaste. Eesti taimenimetused. (= Eesti Teaduste Akadeemia Emakeele Seltsi toimetised 20 (67)). Tallinn, 13-14.

Solženitsõn, Aleksandr 1990. Gulagi arhipelaag. Kirjandusliku uurimuse katse, kd 1 (I-II). Tallinn: Eesti Raamat.

Tender, Tõnu 2000. Emakeele Seltsi keelepäevad 1961-1999: trepp elevandiluust tornist maale. - Emakeele Seltsi aastaraamat 44-45 (1998-1999). Peatoim. Mati Erelt. Tartu: Eesti Teaduste Akadeemia Emakeele Selts, 123-134.

Tender, Tõnu 2019a. Heino Ahvenast (11.11.1919-22.04.1988) arhiivitoimikute valguses. Ettekanne Emakeele Seltsi kõnekoosolekul 08.11.2019.

Tender, Tõnu 2019b. Kujuteldav kiriusutelu Heino Ahvenaga. - Oma Keel 2, 91-95.

Toomessalu, Aadu 1955. Laimjala tuulikutest. - Emakeele Seltsi aastaraamat I. Tallinn: Eesti Riiklik Kirjastus, 134-146.

Traksmaa, August 1992. Lühike Vabadussõja ajalugu. Tallinn: Olion.

Viikberg, Jüri 2019. Heino Ahven keelepäevade karussellis. Ettekanne Emakeele Seltsi kõnekoosolekul 08.11.2019.

\section{Rahvusarhiivi allikad}

$\mathbf{E A A}=$ EAA. $5311.38 / 56.2$

ERAF $=$ ERAF.136SM.1.2598

ERA $=$ ERA.R-292.144 


\title{
A retrospective on the $100^{\text {th }}$ anniversary of Heino Ahven's birth
}

\author{
TÕNU TENDER, JÜRI VIIKBERG
}

The article describes the life and work of the longtime academic secretary of the Mother Tongue Society, Heino Ahven (1919-1988). It includes both well-known as well as little-known and hitherto hidden facts about his life. A brief overview is given of Ahven's education, which was extended and clouded by World War II. With the help of archive material, it is revealed that Ahven was in the German military (March 1943 - September 1944) and was imprisoned during the periods of both German (1943) and Soviet (1944-1945) rule. This is a typical example of the fate of young men who grew up during the first period of independence of the Republic of Estonia.

Heino Ahven's life stabilized when he continued his studies at Tartu State University (1945-1956) and began work as the responsible secretary of the Mother Tongue Society (1947). Devoted to the Estonian language and the Mother Tongue Society, he began to restore the network of dialect correspondents, composed surveys and publications of the Society, organized meetings and conferences, and initiated language days both in the country and in the city. Heino Ahven was everywhere, he became the soul of the Society and of the language events it organized. His voluminous life's work cannot be adequately measured or weighed, but it demands respect and continual remembrance.

Keywords: Heino Ahven, Mother Tongue Society, Estonian, language days, dialect collection

Tõnu Tender

Eesti Keele Instituut

Roosikrantsi 6

10119 Tallinn

tonu.tender@eki.ee
Jüri Viikberg

eesti keele ajaloo, murrete ja

soome-ugri keelte osakond

Eesti Keele Instituut

Roosikrantsi 6

10119 Tallinn

jyri.viikberg@eki.ee 